\title{
Mortgage-equity release: the potential of housing wealth for future Dutch retirees
}

\author{
Janneke Toussaint
}

Received: 15 June 2011/Accepted: 6 June 2012/Published online: 26 June 2012

(C) The Author(s) 2012. This article is published with open access at Springerlink.com

\begin{abstract}
Interest in the use of housing wealth for future retirees is a topic of growing interest amongst policymakers and scientists. Owner-occupiers who are outright owners have lower housing expenses than tenants do, and they have substantial nest eggs. Mortgage markets leapt on this development and offers special products for the elderly, with which they could release their housing wealth. The question in this paper involves the extent to which households build housing equity (i.e. wealth) that could be released. This question is particularly interesting for the Netherlands, the country with the highest mortgage debt per capita in the European Union. This paper aims to combine two different theoretical debates: the debate on "the trade-off between owner-occupation and the welfare state" and the debate on the "life cycle theory". It introduces the concept of the equityto-value ratio, which is derived from the trade-off theory, and reveals the extent to which the people in the Netherlands accumulate housing wealth. This ratio shows that households do build equity. Further analysis indicates that this equity is not built as much by repaying the loan as it is by taking advantage of house price increases.
\end{abstract}

Keywords Housing wealth · Retirement - The Netherlands · Mortgage market

\section{Introduction}

Owner-occupation is not regarded primarily as a pension and, in most countries in the European Union, it is not included in welfare policies. In response to demographic changes, economic globalisation and the current economic downturn, however, pressure on pension systems is increasing and national governments are searching for additional sources of support or income for the current and future retirees in their countries. Housing wealth is obtaining increasing attention in discussions about pension systems. In its most recent Green Paper on pensions, the European Commission states, 'The Internal Market could also be helpful in extending access to additional sources of retirement income

J. Toussaint $(\bowtie)$

Schuttersveld 9, 2611 WE Delft, The Netherlands

e-mail: Janneke.toussaint@gmail.com 
beyond pensions, such as reverse mortgages' (European Commission 2010). Reverse mortgages enable older owner-occupiers to cash in part of their housing wealth while they continue to live in their dwellings. Scholars in the fields of sociology, economics and the multidisciplinary field of housing research are expressing growing interest in the significance of housing wealth in relation to retirement (Chiuri and Jappelli 2010; Costa-Font et al. 2010; Doling and Horsewood 2003; Elsinga et al. 2007; Kemeny 2005; Malpass 2008; Ronald 2008; Rouwendal 2009; Van Gent 2010; Venti and Wise 2001).

The idea that owner-occupation improves the financial well-being of retired people is based on the assumption that owner-occupiers will be outright owners by the time they reach old age. The literature distinguishes roughly two types of roles that owner-occupation can play. First, it reduces housing expenses (Doling and Horsewood 2003; Kemeny 2005; Yates and Bradbury 2010). For instance, Doling and Horsewood (2003) argue that owner-occupation may even facilitate early retirement. Once people own their dwellings outright, owner-occupiers live rent-free, and they are therefore less reliant on income from employment. A second potential role is that housing wealth can be used in line with lifecycle models of saving and consumption; it could thus be consumed in old age (Bonvalet and Ogg 2008; Chiuri and Jappelli 2010; Costa-Font et al. 2010; Ong 2008; Rouwendal 2009). In theory, the optimal pattern of consumption smoothing would involve reducing housing wealth to zero in the period between retirement and the moment that one passes away. For a variety of reasons, however, households are unlikely to consume all of their housing wealth. It nonetheless provides a substantial source of wealth. At least a part of it can be used to supplement pension income either through selling or through equity-release schemes.

In some countries, governments include housing wealth in welfare policies for the elderly (Malpass 2008; Parkinson and Searle 2009). In the UK and (outside Europe) in Australia, popular support for social provisions is relatively low; and pension reforms are characterised by rollbacks in governmental intervention, market-oriented reform, deregulation and privatisation (Frericks 2010; Malpass 2004; Pierson 2002). Owner-occupation offers households the opportunity to accumulate housing wealth, and it is therefore encouraged by the government through tax incentives or subsidies.

In the Netherlands, although owner-occupation is also encouraged through tax incentives, it is not an explicit part of any welfare policy. Its relevance and potential has nonetheless been noticed in research on the asset portfolios of households (AFM 2010; Alessie and Kapteyn 2001; Haffner 2008; Ministry of Social Affairs and Employment 2006; Rouwendal 2009; van de Grift 2009). Four main observations can be made with respect to the potential role of housing wealth in the Netherlands. First, housing wealth has made households affluent (DNB 2008; Haffner 2008). Second, Dutch owner-occupiers are increasingly tending to retain mortgage debt into old age, making outright ownership no longer self-evident (Schors et al. 2007). Third, because taking out additional mortgage debt is more common among younger households, they are expected to plan to use this as a way of obtaining extra cash in their old age. Fourth, it is primarily the higher income groups that become owner-occupiers, and a substantial part of the Dutch population continues to rent (Mulder 2004). Although the group of owner-occupiers is growing, housing wealth is still available only to a limited part of the population.

In this paper, we explore the impact of these four observations on the potential role of housing wealth in old age. Section 2 sets out the relevant literature. The next section discusses the methods used. Section 4 elaborates on the equity to value ratio (ETV) and presents the survey results on equity building. Section 5 presents the survey results on equity release and the paper finishes with a concluding section. 


\section{Theory}

There is an on-going discussion on the link between housing and the welfare state (Kemeny 1981; Castles 1998). Generally, the higher the rate of owner-occupiers in a country, the lower the expenses on collective welfare provision. Moreover, there is a debate on whether housing and more in particular housing equity can be considered as a vehicle in asset based welfare (Sherraden 2003; Doling and Ronald 2010). The process of acquiring a housing asset resembles the process of building up a pension in the sense that it smoothens income over the life course (Barr 2004; Kemeny 1981). Households who plan to purchase a dwelling save for a deposit. When they buy, they invest their savings in the housing asset and the rest they finance with a mortgage loan. During their working lives they gradually repay their mortgage, until they are outright-owner in retirement. Additionally, changes of the market value of the dwelling contribute to the potential of housing wealth for retirement. Housing equity can be considered an alternative for collective welfare state arrangements. The debate focuses for example on the extent to which housing equity can replace a pension (Doling and Elsinga 2012).

The participants in this discussion assume that owner-occupiers are out outright owners by the time they retire. This implicit assumption seems to hold in many cases in many countries, but not for the Netherlands where interest only mortgages became very popular. This paper aims to quantify the implicit assumption in the trade off debate by formulating an ETV-ratio in Sect. 4 and explores to which extent the Netherlands deviates from the ETV that is assumed in theory.

In the last few decades, the share of households entering the owner-occupied sector has been increasing (Doling and Ford 2007). A growing proportion of the households have thus begun to accumulate housing wealth. Owner-occupation has grown in the Netherlands as well, increasing from $42 \%$ in 1985-1957\% in 2008 (WWI 2009). In comparison with older cohorts, younger cohorts are more likely to become owner-occupiers and purchase their first dwellings in an earlier phase of the life course (WWI 2010).

One important development has involved the deregulation of the financial markets since the $1970 \mathrm{~s}$. This has increased access to mortgage credit and thus to owner-occupation (Neuteboom 2008; Stephens 2007). In addition, real house prices in many Western developed countries have increased in recent decades (Girouard and Blöndal 2001). In real terms, the average annual growth rate in the Netherlands was $7.1 \%$ in the period 1991-2000. Between 2001 and 2007, the increases were more moderate, at $3.0 \%$ (Haffner and de Vries 2010). These price developments have increased the relevance of housing wealth in household portfolios. In 2007, $69 \%$ of all assets held by Dutch households consisted of wealth stored in the stones of owner-occupied dwellings (DNB 2008). The greatest potential was obviously for older owner-occupiers, most of whom have reached the end of their mortgage terms, repaid their mortgages and profited from the favourable house-price developments for a longer period.

This reasoning would generally be true, if financial deregulations had only increased access to credit with the purpose of financing owner-occupied dwellings. However, mortgage products developed further. In response to the increasing house prices over the long-term, the owner-occupied dwelling became more important as collateral for additional borrowing. In various countries, households have extensively used the opportunity to borrow to use 'mortgage-equity release' (Catte et al. 2004). Amongst western developed countries, the Netherlands, together with the UK, Australia and Canada, appears to have the highest level of mortgage-equity release. In these countries, house-price increases 
affect private consumption through the mortgage market (Boelhouwer 2002; Catte et al. 2004).

In Australia and the UK, it was found that households facing financial difficulties were more likely to take out an extra mortgage or extend their existing mortgage (Benito 2009; Parkinson and Searle 2009; Schwartz et al. 2008). To date, there have been no indications that households in the Netherlands have been using mortgage-equity release in case of financial difficulties. Equity release through refinancing and second mortgages did contribute significantly to economic growth in the late $1990 \mathrm{~s}$ (Van Els et al. 2003). The rising house prices and the relatively low and decreasing interest rates have been crucial. Most households $(70 \%)$ used their cashed-in housing wealth to renovate their dwellings; $10 \%$ invested it in other investment vehicles or invested it in saving accounts, $8 \%$ reported having consumed it, and $6 \%$ used it for repaying other loans. An additional $6 \%$ of households spent their housing wealth on other purposes (Van Els et al. 2003). In summary, the large-scale use of mortgage-equity release has probably reduced the accumulation of housing wealth towards retirement.

Another trend in the Netherlands, which has also been observed in other developed countries, is the increasing popularity of saving mortgages, investment mortgages and interest-only mortgages over repayment mortgages (DNB and AFM 2009; Scanlon et al. 2008). These types of mortgages delay repayment (endowment mortgages) and are more risky in terms of repayment (investment mortgages), and owner-occupiers who have taken out interest-only mortgages do not intend to repay their mortgages at all. These types of products thus also have an impact on the potential of housing wealth for retirement. In 2008, $47 \%$ of all mortgage products in the Netherlands were interest-only mortgages (DNB and AFM 2009). Van der Schors et al. (2007) have shown a cohort effect for the increase of mortgages in old age.

In general, there seems to be a difference between the attitudes of current retirees regarding mortgage take-up and those of the younger generations. Qualitative research in various countries has suggested that current retirees tend to consider saving more important than younger generations do. In discussions regarding reverse mortgages as a potential way of obtaining extra cash in old age, current retirees were more strongly averse than the members of younger age groups were. To some extent, this can be explained as an age effect. Younger people still have future income prospects, and they find it easier to imagine taking out a mortgage debt. Another explanation is that there is also a cohort effect. Older people more strongly embrace Protestant, Lutheran or Calvinistic values, which hold that saving is 'good' and having debts is 'bad'. These values are likely to be the result of their experiences of times of financial hardship, including wartime, extreme poverty or hunger. Younger generations that have not faced similar conditions would therefore be more open to taking out mortgage debt (Elsinga et al. 2010).

A final issue that is highly prevalent in the literature concerning the actual or potential role of owner-occupation in the context of pension reforms, involves the uneven distribution of owner-occupation over society (Kurz and Blossfeld 2004). In most European countries, and in the Netherlands as well, a substantial part of the population continues to rent, and owner-occupiers are typically the households with higher incomes (Mulder 2004). For Australia, Yates and Bradbury (2010) explain that tenants face a multiple disadvantage in retirement. They must rely on a weaker state pension, they have less private pension savings and they face higher housing expenses. As Malpass (2006) observes for Britain, in the context of pension reform, owner-occupation amplifies inequality.

It is important to note that, in the Netherlands, the developments described above are not only outcomes of market mechanisms; housing policy also has a great impact on the 
potential of owner-occupation as a pension. Dutch housing policy has a profound impact on mortgage take-up and the distribution of housing wealth over the population (Mulder 2004; Wolswijk 2005). Owner-occupiers can deduct the mortgage interest from their income before taxes. Income is taxed against a progressive marginal tax rate, with a maximum of $52 \%$ (Haffner and de Vries 2010). Until 2001, owner-occupiers could profit from the mortgage-interest tax deduction for all types of mortgages, including mortgageequity-release products. The duration of the interest deduction was unlimited. This changed in 2001. Since then, the maximum duration is 30 years and, if the mortgage loan is taken out for any reason other than to finance a dwelling or the renovation of a dwelling, the mortgage-tax deduction cannot be used (Rouwendal 2009). Since 2004, owner-occupiers moving to another owner-occupied dwelling can deduct only the mortgage interest for the part of the loan that reflects the difference between the housing wealth held in the previous dwelling and the price of the new dwelling. Despite these changes, the Dutch government still provides substantial support to owner-occupiers. Dependent on the income level, the net advantage for households younger than 65 years old that make use of the interest relief is between 7 and $13 \%$ of their disposable income (Haffner and de Vries 2010).

Most importantly, the Dutch mortgage-interest deduction intervenes in the potential role of owner-occupation in retirement in two ways. First, the mortgage-interest deduction has made mortgage loans inexpensive, which has had the effect that owner-occupiers tend to borrow more and repay less. The full pattern of consumption smoothingachieving outright ownership upon retirement-has therefore become less common (Commissie_Sociaal-Economische_Deskundigen 2010). Second, due to the incometaxation system, owner-occupation is financially more attractive for the higher income groups, who have a marginal tax rate of $52 \%$, than it is for lower income groups, who have a marginal tax rate of about $33 \%$. Accordingly, owner-occupiers are more likely to be households with higher incomes, while households with lower incomes are more likely to live in the rental sector (Mulder 2004; Schutjens et al. 2002).

\section{Methods}

In the subsequent part of the paper, we focus on owner-occupiers in the Netherlands. The central aim is to explore the potential of housing wealth for future Dutch retirees. We analyse the extent to which owner-occupiers accumulate housing wealth towards retirement; then the mortgage-equity-release practices and finally household plans to release equity for retirement. To be able to consider differences that can originate in different phases in the life course, we distinguish four age groups. The following research questions structure the study:

1. To what extent have Dutch owner-occupiers accumulated housing wealth towards retirement?

2. What proportion of Dutch households has used mortgage-equity release?

3. Were households who experienced financial difficulties more likely to use mortgageequity release than were households who did not?

4. Do households plan to use mortgage-equity release in retirement?

Data on 895 Dutch residents were collected in May 2008 by means of a telephone survey. The sample was stratified, and participants were selected randomly from subgroups based on housing tenure and age (see Table 1). The sample was drawn from a pool of 1.9 
Table 1 Stratified sample for questionnaire survey

\begin{tabular}{llllll}
\hline & Age-groups & & & & \\
\cline { 2 - 6 } & $20-34$ & $35-49$ & $50-64$ & 65 and older & Total \\
\hline Owner-occupiers & 113 & 148 & 123 & 106 & 490 \\
Tenants & 86 & 99 & 116 & 104 & 405 \\
Total & 199 & 247 & 239 & 210 & 895 \\
\hline
\end{tabular}

million addresses and telephone numbers, which is representative of the population of the Netherlands. Of the people contacted, first by letter and later by telephone, $51 \%$ agreed to participate in the telephone survey. The analysis in this paper is based on the results for the 490 owner-occupiers.

The questionnaire consisted of three main parts, which investigated the perceptions of owner-occupation, financial strategies with respect to retirement, and perceptions and use of owner-occupation as a source of wealth. Additional questions concerned housing finance and household characteristics.

To be able to answer the first research question regarding the extent to which Dutch owner-occupiers still accumulate housing wealth, we introduce the concept of the equityto-value ratio (ETV), which is calculated as 1 minus the loan-to-value ratio (LTV) The hypothesis is that Dutch owner-occupiersaccumulate too little equity to become outright owners in retirement. Differences between the age groups were explored. The share of housing wealth emerging from house-price increases was also made visible. The telephone survey provided data on outstanding mortgage debt, the price that respondents paid for their dwellings, the age at which they purchased their dwellings, their current age and the current value of their dwellings. The latter was estimated by asking respondents for the estimation that the municipality makes as a basis for taxes, rather than their own estimations. This was done to avoid overly subjective estimates. About $14 \%$ of the owneroccupiers did not answer the questions on mortgage debts or the price of their dwellings.

One complicated issue concerning outstanding mortgages is that many Dutch mortgagees have saving or investment mortgages with which they save or invest in a separate savings account, life insurance or investment vehicle for the full duration of the mortgage (typically 30 years), with the intent of repaying the mortgage in a single payment at the end of the mortgage term. Of the participants in this telephone survey, about $44 \%$ had savings mortgages, and $16 \%$ had investment mortgages. With these types of mortgages, households benefit optimally from the fiscal arrangements in the Netherlands. At first glance, responses to the question, 'What is your outstanding mortgage debt?' might seem to suggest that they had not yet repaid anything. They had deposited savings into accounts connected to their mortgages, however, indicating that we had underestimated the amount of savings that are connected to owner-occupation. Despite this uncertainty, this unique database, which contains both the perceptions and financial characteristics of households, does allow us to investigate the extent to which Dutch households accumulate housing equity.

To answer the second question (How many households withdrew housing wealth through mortgage equity release?), we asked respondents directly whether they had ever extended their mortgages or taken out second mortgages. We explored differences between age groups. Due to the relatively high level of debt, younger owner-occupiers have probably had fewer opportunities to do so than their older counterparts have had. Further, 
restrictions on the eligibility for the mortgage-interest deductions, which were introduced in 2001, might have made mortgage-equity release less attractive. In addition, the more moderate developments in house prices since 2001 might have slowed the use of mortgageequity release.

To answer the third question, we tested the hypothesis that respondents who have experienced financial difficulties are more likely to have used mortgage-equity release than households who have not. We asked whether respondents had ever experienced either a drop in income or a rise in expenses that had made it difficult for them to afford their monthly housing expenses. The answer to this question was used as an indicator of having or not having experienced financial difficulties.

The fourth research question explores whether households planned to use mortgageequity release in retirement. Respondents were asked whether they would consider this as a way of supplementing their pension income; they were also asked whether they would do this to finance extra care in their old age. 'Extra' here means care beyond the standard care that is covered by insurance and the government. First, we explored whether people who did consider using mortgage-equity release in retirement had higher levels of accumulated wealth (i.e. higher ETV). This could mean that they accumulate more wealth in order to release it in old age. Second, we explored whether people who had already used mortgageequity release were more likely to consider this option in retirement. This would mean that acquaintance with the product and process of equity-release facilitates future use.

Overall, a mix of suitable statistical methods was used, including the independentsample $t$ test $(\mathrm{t})$, ANOVA $(\mathrm{F})$ and Chi-square tests $\left(\chi^{2}\right)$. The data do not allow any conclusions about cohort effects, only about differences between age groups. For statistical tests conducted for respondents from all age groups together, we weighted the sample for age. The weights were calculated using data on housing tenure and age that were obtained from Statistics Netherlands and that cover the entire Dutch population.

\section{Accumulating housing wealth towards retirement-the equity-to-value ratio (ETV)}

The increasing levels of mortgage ownership among the elderly imply that Dutch owneroccupiers are not smoothing their consumption as much as they could. To what extent are they still accumulating housing equity? To explore this question, we introduced the concept of equity-to-value (ETV) ratio to refer to the amount of housing equity that a household holds, as a proportion of the value of the dwelling. In other words, it is the value of the dwelling minus the outstanding mortgage debt, divided by the value of the dwelling. Another definition is 1 minus the loan-to-value (LTV) ratio. The latter concept measures outstanding mortgage debt as a proportion of the value of the dwelling. This term is commonly used in the context of housing finance, if the focus is on mortgage debts (Scanlon and Whitehead 2004).

The mean ETV ratios for the different age groups is shown in Table 2. The youngest age group (20-34 years old) holds approximately $10 \%$ of the value of the dwelling, with the oldest group (65 and older) holding almost $80 \%$. The standard deviation is the highest for the age categories of 35-49 years and 50-64 years. The greatest diversity in strategies regarding the accumulation of housing wealth can therefore be found amongst these two groups.

To evaluate the extent to which Dutch owner-occupiers accumulate housing wealth towards retirement, we also calculated an $\mathrm{ETV}_{\text {expected }}$ value for all respondents. The initial assumption is that non-retired people aim to own their dwellings outright at the official 
Table 2 Descriptive statistics on equity-to-value ratios (ETV) for different age groups

\begin{tabular}{llll}
\hline Age group & N & Mean & SD \\
\hline $20-34$ & 96 & 0.089 & 0.218 \\
$35-49$ & 116 & 0.339 & 0.345 \\
$50-64$ & 113 & 0.589 & 0.316 \\
65 and older & 96 & 0.781 & 0.280 \\
\hline
\end{tabular}

retirement age of 65 years. Hence, at the age of purchase, the ETV expected is 0 , and at the age of 65 , the ETV expected is 1 . We assume that households accumulate housing wealth according the annuity formula, as most of the Dutch save in saving and annuity mortgages, in which payments occur accordingly. At the beginning of the mortgage term, hardly any capital has been built up, and the largest part of the monthly expenses is spend on the interest, with only a small part used to accumulate capital. In due course, when the saved capital becomes more substantial, less is spent on interest and more is used to accumulate capital.

$$
\begin{aligned}
\mathrm{a} & =\left[\mathrm{P}(1+\mathrm{r})^{\mathrm{n}} \mathrm{r}\right] /\left[(1+\mathrm{r})^{\mathrm{n}}-1\right] \\
\mathrm{LTV}_{\text {expected }} & =\mathrm{P}(1+\mathrm{r})^{\mathrm{Y}}-\mathrm{a}\left[\left((1+\mathrm{r})^{\mathrm{Y}}-1\right) /((1+\mathrm{r})-1)\right]
\end{aligned}
$$

If Age $<65: \mathrm{ETV}_{\text {expected }}=1-\mathrm{LTV}_{\text {expected }}$

a annuity, $\mathrm{P}$ total debt at the moment of purchase, $\mathrm{r}$ interest rate, $\mathrm{n}$ total number of instalments, Y number of terms respondent owns dwelling at moment of survey.

The symbol 'a' represents the annuity - the theoretical amount that needs to be paid in every instalment. The ' $\mathrm{P}$ ' represents the total debt at the time of purchase, which we set as 1. Households start with a LTV ratio of 1 and an expected LTV ratio of 0 at the age of 65. The ' $n$ ' represents the total number of instalments during which a respondent will accumulate housing equity up to outright ownership. Hence, $\mathrm{n}$ is 65 minus the age of purchase. This means that we have simplified the process of housing wealth accumulation and that we did not consider steps on the housing ladder. Further, we applied a uniform interest rate (r) of $4.90 \%$, as this was the average interest rate for $99.5 \%$ of all mortgages in 2008 (DNB 2010).

The $\mathrm{LTV}_{\text {expected }}$ is the part of the debt that respondents still needed to repay at the time that the survey took place, at their current age, if their goal was outright ownership. ' $\mathrm{Y}$ ' represents the number of terms (in this case, years) that the respondents had owned the dwelling at the time of the survey (i.e. current age minus age at purchase). The ETV $_{\text {expected }}$ can be then calculated as 1 minus the $\mathrm{LTV}_{\text {expected. The }} \mathrm{ETV}_{\text {expected }}$ is calculated only for respondents who were not retired, in order to examine the accumulation phases in the life course.

The next important step is to calculate the difference between the ETV and the $\mathrm{ETV}_{\text {expected}}$, which we call ETV $\mathrm{Eev}_{\text {de }}$ It is the deviance between the actual and the expected ETV ratio.

$$
\mathrm{ETV}_{\mathrm{dev}}=\mathrm{ETV}-\mathrm{ETV}_{\text {expected }}
$$

If the ETV $\mathrm{dev}_{\text {is }}$ negative, it means that people have accumulated less housing wealth than expected, and that they are not accumulating sufficient housing wealth in order to become outright owners at the official retirement age. If the outcome is positive, they are building up more wealth than expected. 


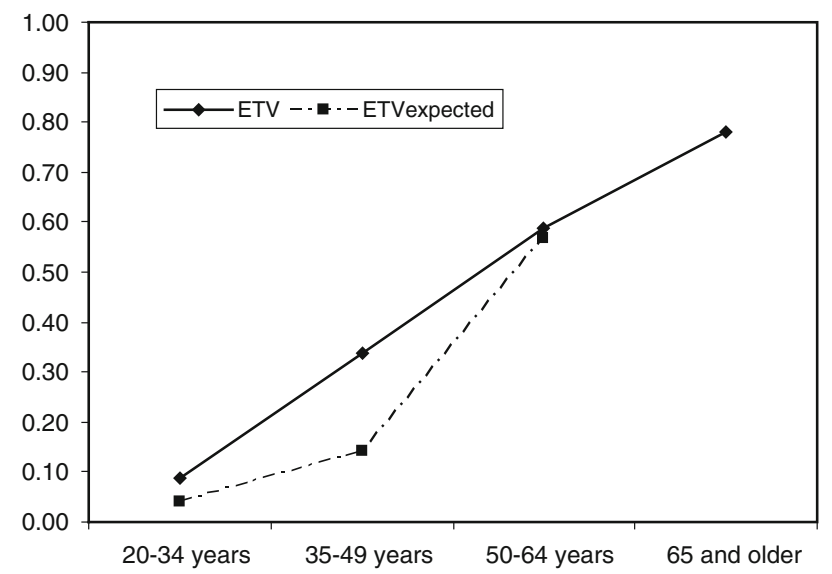

Fig. 1 Actual and expected equity-to-value ratio (ETV) in four different age groups in The Netherlands

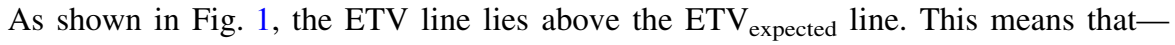
contrary to the hypothesis - in all three age groups younger than 65 , households had actually built up more ETV than expected. If we consider the differences between the age groups, those between the ages of 50 and 64 had accumulated only slightly more housing wealth than expected, while those between 35 and 49 years had accumulated substantially more. Differences in $\mathrm{ETV}_{\mathrm{dev}}$ between age groups were significant $(\mathrm{F}(2,322)=12.0$, $p=0.00)$. Since it is known that the Dutch tend to not repay their mortgages and even withdraw housing wealth, the positive deviance (ETV ratios that are higher than expected) must be due to increases in house prices.

In Fig. 2, we show the part of the total ETV that is built up through repayment of the mortgage $\left(\mathrm{E}_{\mathrm{r}} \mathrm{TV}\right)$, as well as the part that emerges through increases in the value of the dwelling $\left(E_{p} T V\right)$. The $E_{p} T V$ is calculated by dividing the price increase (current value of the dwelling minus the value of the dwelling at the time of purchase) by the value of the dwelling. The $\mathrm{E}_{\mathrm{r}} \mathrm{TV}$ is calculated by extracting the $\mathrm{E}_{\mathrm{p}} \mathrm{TV}$ from the ETV ratio.

As shown in the figure, for all age groups, most of the ETV is obtained through house price increases. The figure also reveals that the oldest two age groups had obtained about the same proportion of wealth from price increases, but that those aged 65 and older had a higher $\mathrm{E}_{\mathrm{r}} \mathrm{TV}(\mathrm{M}=0.24, \mathrm{SD}=0.38)$ than did those between the ages of 50 and 64 $((\mathrm{M}=0.04, \mathrm{SD}=0.33), \mathrm{t}(204)=-4.0, p=0.00)$. Households between the ages of 35 and 49 had built up a remarkably small amount through mortgage repayment, while the youngest group had not actually made any contribution to the ETV. All of the wealth that had been accumulated by the youngest households had been generated by price increases. The negative $\mathrm{E}_{\mathrm{r}} \mathrm{TV}$ can be explained by the high mortgage take-up by first-time buyers. In the Netherlands, mortgage debt can exceed the value of the dwelling (Scanlon and Whitehead 2004).

\section{Mortgage-equity release}

We found significant differences between the age groups with regard to the frequency of using mortgage-equity release $\left(\chi^{2}(3, \mathrm{~N}=490)=21.5, p=0.00\right)$. Households between 


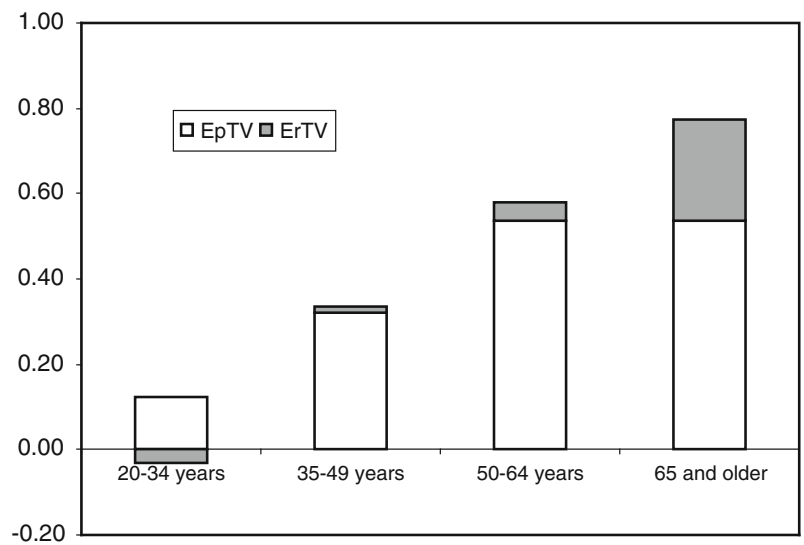

Fig. 2 Equity-to-value ratio (ETV) accumulated through mortgage repayment (ErTV) and house price increase (EpTV) in The Netherlands

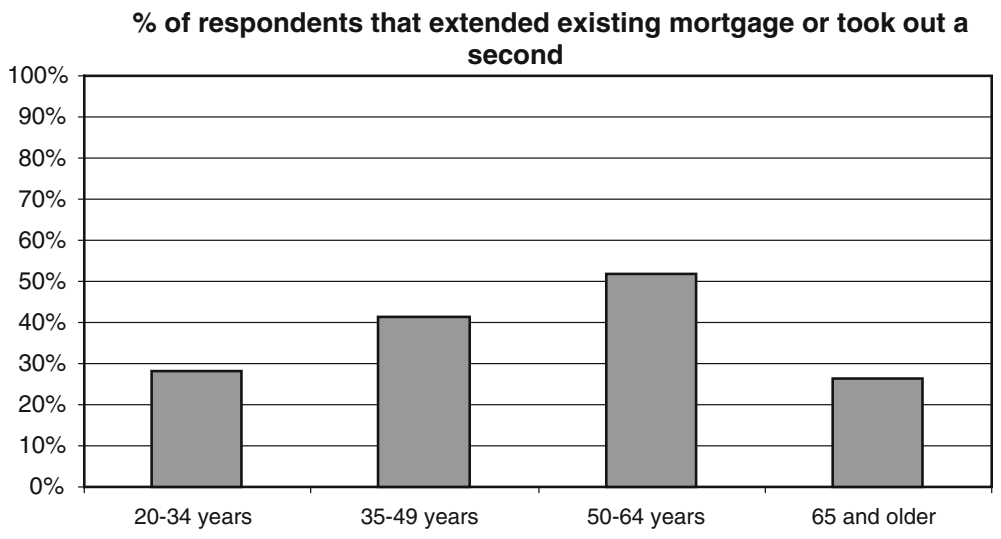

Fig. 3 Borrowing against home as collateral in four different age groups in The Netherlands

the ages of 50 and 64 were especially likely to have used this option to obtain extra cash; $52 \%$ had extended their existing mortgages or taken out additional mortgages. This was more than in the two youngest groups and, remarkably, more than in the oldest group (see Fig. 3). Once again, differences between the two oldest age groups were significant: $\left(\chi^{2}(1, \mathrm{~N}=229)=15.5, p=0.00\right)$. The future generation of retirees has apparently found it easier to use mortgage products to increase consumption than have the current elderly. Unfortunately, here we cannot disentangle whether this is due to an age or cohort effect.

We subsequently investigated whether people who had experienced financial difficulties had used mortgage-equity release more often than those who had not experienced such difficulties. Overall, almost $15 \%$ of all respondents indicated having experienced financial difficulties with making ends meet. To carry out a valid Chi-square test, we added the responses from all age groups together. The findings indeed suggest that a significantly higher proportion of the owner-occupiers $(53 \%)$ who had experienced financial drawbacks had used mortgage-equity release than had owner-occupiers who had not experienced financial difficulties $(39 \%)\left(\chi^{2}(1, \mathrm{~N}=488)=4.2, p=0.03\right)$. 


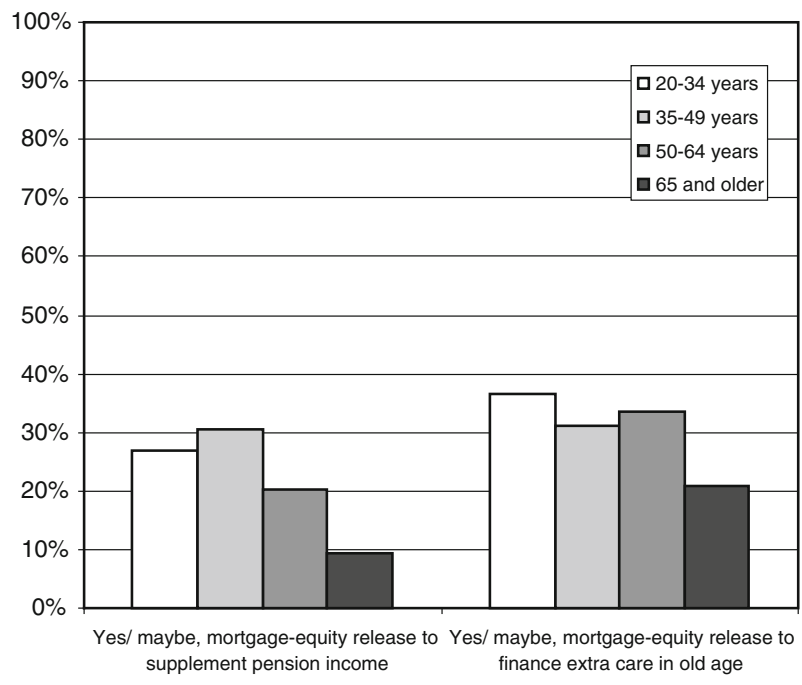

Fig. 4 Considerations regarding the use of mortgage-equity release to supplement pension income or to finance extra care in The Netherlands

We then explored whether households were planning to use mortgage-equity release in retirement. First, respondents were asked whether they would consider this in order to supplement their pension income. Overall, $23 \%$ responded 'yes' or 'maybe', when asked if they would use mortgage-equity release to supplement to their pension incomes. Differences between age groups were significant $\left(\chi^{2}(3, \mathrm{~N}=488)=17.4, p=0.00\right)$. As shown in Fig. 4, the older age groups were less likely to consider this option than the younger age groups were. Respondents were also asked whether they would do this in order to finance extra care in old age. Overall, households seemed somewhat more positive about the use of mortgage-equity release for this purpose (overall, $31 \%$ indicated 'yes' or 'maybe'). Especially amongst the oldest groups, this appeared to be a more acceptable purpose for consuming housing wealth. Of the respondents aged 65 and older, only $9 \%$ said that they would consider using this option for additional income, while $21 \%$ would consider it in order to finance extra care. As before, differences between age groups were significant: $\left(\chi^{2}(3, \mathrm{~N}=488)=7.3, p=0.03\right)$. Especially in the oldest group, fewer respondents would consider using mortgage-equity release in retirement (see Fig. 4).

We then explored whether the people who were willing to consider using mortgageequity release had higher levels of accumulated wealth (i.e. higher ETV ratios). This could mean that they had accumulated more wealth in order to release it in their old age. No higher level of accumulated housing wealth was found amongst respondents who would consider using mortgage-equity release for additional pension income or amongst those who would do so in order to pay for extra care $(\mathrm{t}(419)=0.42, p=0.34$, and $\mathrm{t}(419)=$ $-0.26, p=0.40$, respectively).

Hence, respondents who indicated that they would consider using mortgage-equity release in retirement had not accumulated significantly more housing wealth than those who would not consider this option.

We subsequently explored whether people who had already used mortgage-equity release were more likely to consider using this option for retirement as well. Indeed, we find significant differences between people who had already used mortgage-equity release 


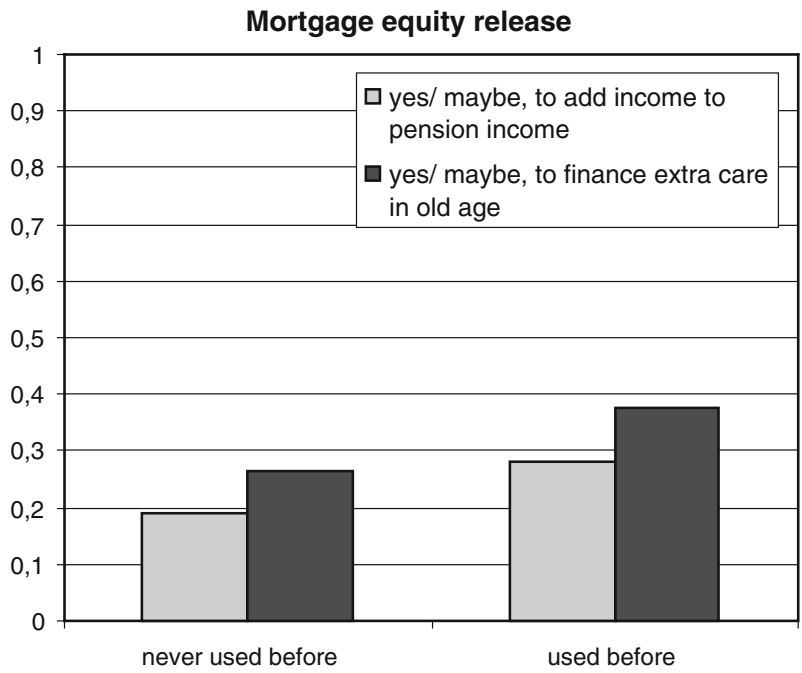

Fig. 5 Considerations regarding the use of mortgage-equity release in retirement, by those who have used mortgage-equity release before and those who have not (The Netherlands)

and those who had not.These differences were observed amongst those who would consider mortgage-equity release to supplement their pension income $\left(X^{2}(1, N=488)=5.3\right.$, $p=0.01)$, as well as amongst those who would consider using it in order to finance extra care $\left(\chi^{2}(1, \mathrm{~N}=488)=6.3, p=0.00\right)$. Figure 5 shows the differences. This finding suggests that familiarity with mortgage-equity-release products and the process of equity release facilitates the consideration to use it in retirement again.

\section{Conclusions}

Owner-occupation could be used optimally as a pension through outright ownership. First, this considerably reduces housing expenses. Second, retired owner-occupiers have substantial nest eggs, which they can use through selling or through equity-release products in case of financial need. In the Netherlands, an increasing proportion of households have purchased dwellings, and an increasing proportion of the population thus has the possibility of using owner-occupation as a pension. At the same time, however, mortgage borrowing has also increased in the Netherlands, and the elderly are increasingly tending to retain mortgage debt into old age. One element within various mortgage practices has been mortgage-equity release. The central aim of this paper was to explore the potential of housing wealth in the Netherlands for future retirees.

One vital issue that emerged from the literature study is that, in the Netherlands, housing wealth is a potential source of wealth, most typically for the higher income groups. Households with lower incomes are more likely to be housed in the rental sector, and they therefore do not have similar amounts of wealth available in old age. Housing policies, specifically the mortgage-interest deduction, appears an influential factor in this wealth gap between tenants and owner-occupiers in retirement.

We now offer a brief summary of the outcomes of the questionnaire survey held in 2008. One initial expectation was that Dutch households do not accumulate sufficient 
housing wealth in order to become outright owners in old age, due to the high level of initial and additional mortgage borrowing. Contrary to this expectation, our application of the concept of equity-to-value ratio (ETV) revealed that households still accumulate more than expected. The level of wealth built up through mortgage repayment appears alarmingly low, however, whereas the gains from the housing market appear of utmost importance for the accumulation of housing wealth.This might be an adequate strategy in times of house price increases, but is a worrying one in particular for recent buyers in times of house price decreases.

Mortgage-equity release has been used on a large scale. We expected its use to be higher amongst the older age groups than amongst the younger groups, as older households have been able to profit from house-price increases for a longer time, and because they had been asset-rich in the time that mortgage-interest deduction was unlimited for all types of mortgage debt. We found that owner-occupiers between the ages of 50 and 64 were especially likely to have used-mortgage equity release, but not the oldest group (i.e. the current retirees). This suggests that there could be a difference between the current old and younger generations with regard to attitudes towards mortgage borrowing. Further, as in other countries, we found that owner-occupiers in the Netherlands who had experienced financial hardship were more likely to have used mortgage-equity release than were households who had not experienced such problems.

We found that a small but significant proportion of the owner-occupiers would consider using mortgage-equity release in retirement. Releasing equity in order to pay for extra care in old age is more often regarded as appropriate than is releasing equity to supplement pension income. Owner-occupiers who indicated that they would consider mortgage-equity release had not accumulated more housing wealth (more ETV) specifically for this purpose. Instead, they were more likely to have used mortgage-equity release in the past.

When observing the development of increasing mortgage debts among the Dutch elderly, the question arises whether older owner-occupiers who are in debt could be at risk. Reflecting on the two roles that owner-occupation can play in retirement-having reduced housing expenses and having a nest egg - the consequences of the limited accumulation of housing wealth and the outstanding mortgage debt depend primarily on income and expenses. As long as retired households can make ends meet and can afford their monthly mortgage expenses, the mortgage debt will not have any consequences. More research is necessary in order to gain insight into the risks for indebted owner-occupiers. Topics of particular interest include the extent to which pension reforms in the Netherlands will affect the future pension incomes of this group, and developments that will determine their future housing expenses. It should also be taken into account that saving mortgages, investment mortgages and similar mortgage types typically hide part of the capital that is being accumulated in order to repay the mortgages. In the future, questionnaires should be developed in such a way that they provide better insight into the assets accumulated in savings accounts and investment vehicles that are intended to repay the mortgage. These facilities should be considered when discussing the consequences of mortgage debt amongst the elderly.

Dutch households that are unable to make ends meet must either reduce their expenses or increase their income. Households can choose from amongst various strategies. Even for dwellings that are not owned outright, owner-occupation can still play a role in the strategy as a nest egg. Indebted older owner-occupiers still have substantial nest eggs due to house price increases. The crucial factor will be whether they have opportunities for cashing in their housing wealth. Are they able to sell their house and move to a less expensive 
dwelling? Can they sell and find affordable rental housing? What are the possibilities on the mortgage market?

As long as owner-occupiers are able to cash in their housing wealth, the current way of accumulating housing wealth in the Netherlands has turned out rather well, especially for the older age groups. They usually bought at the 'right' time, before the late $1990 \mathrm{~s}$, and they used mortgage-equity release when substantial gains were made on the housing market. In general, however, it seems that Dutch owner-occupiers have become increasingly dependent on house-price developments, and it is uncertain whether these favourable developments will be similar for future generations. Households that experience financial difficulties and use mortgage-equity release are more vulnerable to situations involving decreases in house prices.

For owner-occupiers, the limited deductibility of mortgage interest will become apparent for the first group of elderly in 2031. If no changes occur in current mortgageborrowing practices, a substantial proportion of owner-occupiers will face increasing mortgage expenses. Owner-occupiers might seek ways to cash in their housing wealth, which will most likely have consequences for dynamics on the housing market and the mortgage market. For tenants, the wealth gap will become increasingly visible due to the pension reforms. Compared to owner-occupiers, tenants have lower income and fewer assets, and they lack the possibility of obtaining extra cash. The mortgage-interest deduction has magnified the differences between the asset portfolios of owner-occupiers and those of tenants. The mortgage-interest deduction, its impact on mortgage borrowing and its effect on the distribution of housing wealth are highly undesirable in the context of pension reforms. For these reasons, the gradual repeal of the mortgage-interest deduction seems appropriate.

Open Access This article is distributed under the terms of the Creative Commons Attribution License which permits any use, distribution, and reproduction in any medium, provided the original author(s) and the source are credited.

\section{References}

AFM (2010). Geef Nederlanders pensioeninzicht. Werken aan vertrouwen door dichten van de verwachtingskloof. Amsterdam (AFM).

Alessie, R. J. M., \& Kapteyn, A. (2001). Savings and pensions in The Netherlands. Research in economics, $55,61-82$.

Barr, N. (2004). The economics of the welfare state. Oxford: Oxford University Press.

Benito, A. (2009). Who withdraws housing equity and why? Economica, 76(301), 51-70.

Boelhouwer, P. (2002). Capital accumulation via homeownership: The case of the Netherlands. European Journal of Housing policy, 2(2), 167-181.

Bonvalet, C., \& Ogg, J. (2008). The housing situation and residential strategies of older people in France. Ageing and Society, 28, 753-777.

Castles, F. G. (1998). The really big trade-off: home ownership and the welfare state in the new world and the old. Acta Politica, 33(1), 5-19.

Catte, P., Girouard, N., Price, R., \& André, C. (2004). 2004. The contribution of housing markets to cyclical resilience. OECD economic studies, $3(8), 1$.

Chiuri, M., \& Jappelli, T. (2010). Do the elderly reduce housing equity? An international comparison. Journal of Population Economics, 23(2), 643-663.

Commissie_Sociaal-Economische_Deskundigen (2010). Naar een integrale hervorming van de woningmarkt. Den Haag: Sociaal-Economische Raad.

Costa-Font, J., Gil, J., \& Mascarilla, O. (2010). Housing wealth and housing decisions in old age: Sale and reversion. Housing studies, 25(3), 375-395.

DNB. (2008). Vroegpensioen, de levensloopregeling en het vermogen van Nederlandse huishoudens. DNB/ Kwartaalbericht, Maart, 2008, 33-38. 
DNB (2010). Market interest rates: Yearly, Monthly, T1.2.1. Amsterdam (De Nederlandsche Bank).

DNB \& AFM (2009). Risico's op de hypotheekmarkt voor huishoudens en hypotheekverstrekkers. Amsterdam.

Doling and Elsinga. (2012). Demographic change and housing wealth, home owners, pensions and asset based welfare in Europe. Dordrecht: Springer.

Doling, J., \& Ford, J. (2007). A union of homeowners? European Journal of Housing Policy, 7(2), 113-127.

Doling, J., \& Horsewood, N. (2003). Home ownership and early retirement: European experience in the 1990 s. Journal of Housing and the Built Environment, 18, 289-308.

Doling, J., \& Ronald, R. (2010). Property-based welfare and European homeowners: how would housing perform as a pension? Journal of Housing and the Built Environment, Special Issues, Home ownership and asset-based welfare, 25(2), 227-241.

Elsinga, M., De Decker, P., Teller, N., \& Toussaint, J. (Eds.) (2007). Home ownership: beyond asset and security. Perceptions of housing related security and insecurity in eight European countries, Housing and Urban Policy Studies 32. Amsterdam (IOS Press).

Elsinga, M., Jones, A., Quilgars, D., \& Toussaint, J. (2010). Households' perceptions on old age and housing equity—Combined report WP2 http://www.demhow.bham.ac.uk/reports/A4.pdf. Demographic change and housing wealth: Project funded under the Socio-economic Sciences and Humanities-EU 7th framework programme.

EuropeanCommission (2010). Towards adequate sustainable and safe European pension systems-Green paper. Luxembourg (Publications Office of the European Union).

Frericks, P. (2010). Capitalist welfare societies' trade-off between economic efficiency and social solidarity. European Societies, 12(5), 719-741.

Girouard, N., \& Blöndal, S. (2001). House prices and economic activity: OECD.

Haffner, M. E. A. (2008). Savings for old age? Housing wealth of the Dutch elderly. Housing, Theory and Society, 25(2), 110-131.

Haffner, M., \& de Vries, P. (2010). Dutch houseprices and tax reform. In M. Stewart (Ed.), Housing and tax policy (pp. 151-173). Sydney: Australian Tax Research Foundation.

Kemeny, J. (1981). The Myth of home-ownership. Private versus public choices in housing tenure. London: Routledge \& Kegan Paul.

Kemeny, J. (2005). "The really big trade-off” between home ownership and welfare: Castles' evaluation of the 1980 thesis, and a reformulation 25 years on. Housing, Theory and Society, 22(2), 59-75.

Kurz, K. \& Blossfeld, H.-P. (Eds.). (2004). Home ownership and social inequality in comparative perspective. Stanford (Stanford University Press).

Malpass, P. (2004). Fifty years of British housing policy: Leaving or leading the welfare state. European Journal of Housing Policy, 4(2), 209-227.

Malpass, P. (2006). Housing policy in an 'opportunity society'. Homeownership and the amplification of inequality. In J. Doling \& M. Elsinga (Eds.), Homeownership. Getting in, getting from, getting out. Part II (pp. 109-126). Amsterdam: IOS Press.

Malpass, P. (2008). Housing and the new welfare state: Wobbly pillar or cornerstone? Housing studies, 23(1), 1-19.

Ministry of Social Affairs and Employment (2006). De toekomstige inkomenspositie van ouderen. Den Haag.

Mulder, C. (2004). Home ownership and social inequality in the Netherlands. In K. Kurz \& H.-P. Blossfeld (Eds.), Home ownership and social inequality in comparative perspective. Stanford: Stanford University Press.

Neuteboom, P. (2008). On the rationality of borrowers' behaviour: Comparing risk attitudes of homeowners (dissertatie). Amsterdam: IOS Press.

Ong, R. (2008). Unlocking housing equity through reverse mortgages: The case of elderly homeowners in Australia. European Journal of Housing Policy, 8(1), 61-79.

Parkinson, S., \& Searle, B. (2009). Mortgage equity withdrawal in Australia and Britain: Towards a wealthfare state? European Journal of Housing policy, 9(4), 365-389.

Pierson, P. (2002). Coping with permanent austerity: Welfare state restructuring in affluent democracies. Revue Française de Sociologie, 43(2), 369-406.

Ronald, R. (2008). The ideology of home ownership: Homeowner societies and the role of housing. London: Palgrave Macmillan.

Rouwendal, J. (2009). Housing wealth and household portfolios in an ageing society. De Economist, 157(1), $1-48$.

Scanlon, K., Lunde, J., \& Whitehead, C. (2008). Mortgage product innovation in advanced economies: More choice, more risk. European Journal of Housing Policy, 8(2), 109-131. 
Scanlon, K., \& Whitehead, C. (2004). International trends in housing tenure and mortgage finance. London: London School of Economics.

Schors, A., van der, Alessie, R. J. M., \& Mastrogiacomo, M. (2007). Home and mortgage ownership of the Dutch elderly: Explaining cohort, time and age effects, Social and economic dimensions of an aging population. Hamilton, Ontario, Canada.

Schutjens, V. A. J. M., van Kempen, R., \& van Weesep, J. (2002). The changing tenant profile of Dutch social rented housing. Urban Studies, 39(4), 643-664.

Schwartz, C., Lewis, C., Norman, D., \& Hampton, T. (2008). Factors influencing housing equity withdrawal: Evidence from a microeconomic survey. Economic Record, 84(267), 421-433.

Sherraden, M. (2003). Assets and the social investment state. In W. Paxton (Ed.), Equal shares: Building a progressive and coherent asset-based welfare policy (pp. 28-41). London: IPPR.

Stephens, M. (2007). Mortgage market deregulation and its consequences. Housing Studies, 22(2), 201-220.

van de Grift, M. (2009). Pensioenaanspraken en vergrijzing. Den Haag: Centraal Bureau voor de Statistiek.

van Els, P., van den End, J., \& Van Rooij, M. (2003). Financial behaviour of Dutch households: analysis of the DNB Household Survey 2003. Amsterdam: De Nederlandsche Bank.

Van Gent, W. P. C. (2010). Housing policy as a lever for change? The politics of welfare, assets and tenure. Housing Studies, 25(5), 735-753.

Venti, S., \& Wise, D. (2001). Aging and housing equity: Another look. NBER Working Paper.

Wolswijk, G. (2005). On some fiscal effects on mortgage debt growth in the EU: European Central Bank. WWI (2009). Cijfers over Wonen, Wijken en Integratie 2009. Den Haag (Ministerie van VROM).

WWI (2010). Senioren op de woningmarkt. Nieuwe generaties, andere eisen en wensen. Den Haag (VROM/ Wonen, Wijken en Integratie).

Yates, J., \& Bradbury, B. (2010). Home ownership as a (crumbling) fourth pillar of social insurance in Australia. Journal of Housing and the Built Environment, 25(2), 193-211. 